International Journal of Health Sciences
Available online at http://sciencescholar.us/journal/index.php/ijhs
Vol. 3 No. 3, December 2019, pages: $33 \sim 43$
e-ISSN: 2550-696X, p-ISSN: 2550-6978
http://dx.doi.org/10.29332/ijhs.v0i0.000

\title{
High-Risk Sexual Behavior among Dakocan (Female Coffee Seller)
}

\author{
(D) crossMark \\ Iwan Saka Nugraha a
}

Article history: Received 18 May 2019, Accepted: 31 August 2019, Published: 08 November 2019

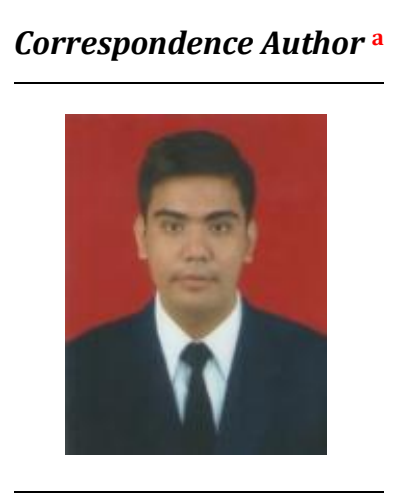

Keywords

female;

HIV/AIDS;

knowledge;

perception;

sexual behavior;

\begin{abstract}
HIV/AIDS cases among female sex workers in Buleleng regency was suspected related to the increasing number of indirect sex workers. Coffee sellers named dakocan who are not only selling coffee, or various food but also providing alcoholic drink and sexual service. This study aimed to provide an overview of high-risk sexual behavior among dakocan and its determinants. The study applied a mixed-method design. First of all, the survey was conducted among 64 respondents. 14 confirmed that they were also providing sexual services who were further interviewed more deeply to know the sexual behavior related to high risk of HIV transmission. Quantitative analysis the respondents were having poor knowledge regarding HIV/AIDS (59.38\%) and not a serious disease $(62,50 \%)$ and $59.38 \%$ having a low perception ,as much as $67,19 \%$ respondents perceived that they are having a high-risk variables that are significant low perception toward benefits of using condoms $(95 \% \mathrm{CI}=0.002$ 0.759; $\mathrm{p}=0.032$ ), experience in undergoing HIV/AIDS examination (95\%CI=1.039-182.903; $\mathrm{p}=0.047)$. These findings are supported by the qualitative interview. The government program is required to change dakocan behavior by providing preventive services including more campaigns in the importance of condoms.
\end{abstract}

e-ISSN: 2550-696X, p-ISSN: 2550-6978 ${ }^{\circ}$ Copyright 2019. The Author. SS Journals Published by Universidad Técnica de Manabí. This is an open-access article under the CC BY-SA 4.0 license (https://creativecommons.org/licenses/by-sa/4.0/) All rights reserved.

\section{Contents}

Abstract 33

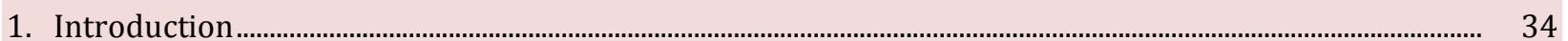

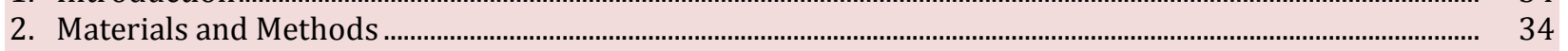

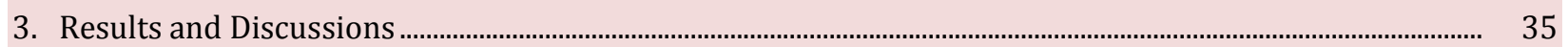

3.1 Characteristics of Research Subjects .......................................................................................................... 35

3.2 An Overview of the Sexual Behavior of Risk in Dakocan ................................................................................. 36

3.3 Sexual Behavior of Risk ........................................................................................................................................... 37

a Udayana University, Denpasar, Bali 
3.4 Influential Variables on the Sexual Behavior of HIV Transmission Risk...................................................... 39

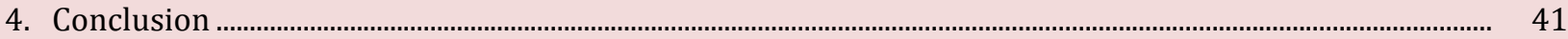

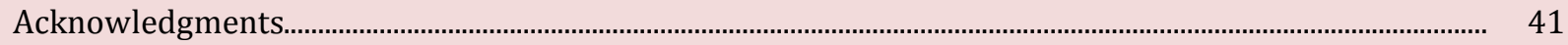

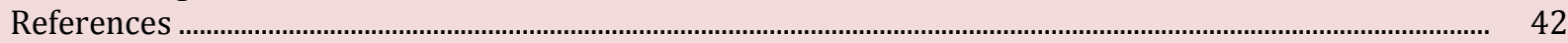

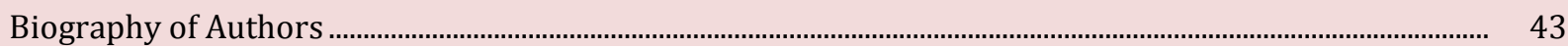

\section{Introduction}

The worldwide prevalence of the Human Immunodeficiency Virus (HIV) in 2014 varies widely, in the United States by 4\%, in South Africa by 18\%, while in Thailand by $1.4 \%$ (UNAIDS, 2014). Then an increase in 2016 found 78 million residents in the world positive for HIV, from that lift $11.4 \%$ or about 8.9 million a new case. In the Asia Pacific, it is known as 5.1 million residents have HIV (UNAIDS, 2016). In Indonesia, the first case of HIV was first discovered in 1987 and there was an increase in HIV cases year after year. The Ministry of Health data in 2015 reported the number of HIV cases as 30,935 people, increasing to 41,250 people in 2016, while in 2017 it increased to 48,300 people (Ditjen P2P, 2018).

The prevalence of HIV/AIDS among Women Sex Workers (PSP) is currently still high. Based on HIV/AIDS and STI (SIHA) information system report data in 2017 the prevalence of HIV cases on PSPs amounted to 2.06\% (Ditjen P2P, 2017). From the Bali Province AIDS Countermeasures Commission data of 2018 put Buleleng in the third position, the number of PSPs in Buleleng was recorded to be 1,035 inhabitants, of which $20 \%$ or about 200 people contracted HIV/AIDS (Komisi Penanggulangan AIDS Daerah Kabupaten Buleleng, 2018).

The number of HIV cases in Buleleng County in 2018 amounts to 2,953 cases (Dinas Kesehatan Kabupaten Buleleng, 2017). The development of HIV in Buleleng County is often associated with the growing number of coffee shops. Coffee stalls are generally guarded by a female better known by the trade term beautiful coffee (dakocan). The dakocan also provides coffee drinking services with additional services such as hugging the merchants, kissing, groping, oral sex, and body-related, so even the price is different. The service price of the dakocan services is quite cheap because its operating area is included in rural areas (Sanjaya, 2013; Mulyani et al., 2017).

Other research results in Jember on the attitude and impact of the dakocan in public health show that large as a society does not dispute the existence of dakocans and there is no good system to minimize the potential deviation of sexual activity committed by the dakocans and customers. There is a requirement for a clear regulation by situation analysis involving the region's policy-holders and the existence of further research qualitatively on the dakocan activity (Ririanty \& Nafikadini et al., 2015; Markolinda \& Sawirman, 2018).

Early studies were conducted by interviewing ten dacocans to seek information required by researchers in order to be able to determine research problems and provide an overview of later research plans, for example, usable research designs. The results found in the preliminary study showed that seven dakocans never used condoms when doing sexual intercourse with their partners. They had as many as four customers per week and had sexual intercourse without the use of condoms. Related to the problem, the study has been implemented to find out and explain HIV-infected risky sexual behavior in the dakocans in the Western part of Buleleng County along with its determinants.

\section{Materials and Methods}

The study used mixed method research designs, with quantitative (cross-sectional) and qualitative research approaches. The study is located in the Western Buleleng County area covering six research areas. The dakocan stalls have been in operation since 16:00-23:00 wita and there are approximately 3-4 dakocans standing guard in a single whitewater. Of the 6 regions are 30 dakocan stalls scattered across each region as described in figure 1 of the following. 
Description:

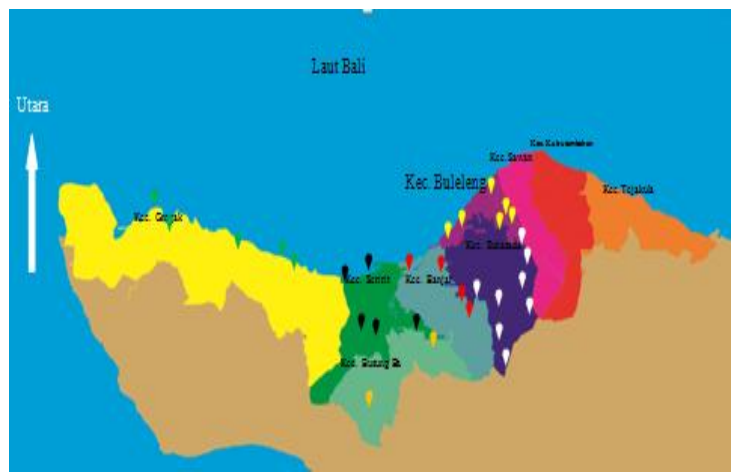

Figure 1.30 dakocan stalls scattered across each region Source: (YCUI, 2016)

1) Young Purple : Kec. City's melting

2) Purple : Kec. Sukasada

3) Green : Kec. Seririt

4) Yellow : Kec.Gerogak

5) Young Blue : Kec. Banjar

6) Young Green : Kec. Busung biu

Quantitative data collection begins with quantitative surveys to generate the initial picture of knowledge, perception and risky sexual behavior of dakocans. A total of 64 dakocan respondents were selected randomly (simple random sampling) from 200 lists of dakocan names obtained from the Usada Indonesia Image Foundation (YCUI) register to be interviewed using structured questionnaire guides. Before the interview process was implemented, the researchers made a persuasive approach with dakocan by asking for the help of some local youth to be more accepted by dakocans and coffee shop owners. This approach takes two weeks. The selection of respondents was conducted based on inclusion criteria and exclusion criteria. The criteria for inclusion in this study namely the dakocan trading in the Western Region of Buleleng Regency recorded in the YCUI range register book, a dakocan willing to take part in the study by signing informed consent, a dakocan that understands Indonesian. Whereas, the exclusion criteria in this study are those experience health problems so they cannot be interviewed. The resigned respondents were replaced with other respondents according to the list of names that had been prepared.

Later from the results of quantitative surveys, as many as 14 respondents who claimed to provide sexual services to customers were interviewed further to explore sexual behavior at risk of HIV transmission, namely condom use behavior, customer count, frequency of sexual intercourse with customers and HIV/AIDS examination experience. In addition, in this in-depth interview, respondents were also given questions regarding the habit of alternating sexual partners, unprotected sexual intercourse behavior within a month, safe sex behavior, social-environmental support, HIV/AIDS examination experience, and self-preservation efforts or behaviors of HIV/AIDS disease. Before research was implemented, the study had been approved by the ethics committee of the medical faculty of Udayana University, with a decree permit number 2167/UN14.2.2.VII.14/LP/2018 dated October 15, 2018.

\section{Results and Discussions}

\subsection{Characteristics of Research Subjects}

From the results of the interview, it was known that $84.40 \%$ of dakocans had bosses, while only $15.60 \%$ were selling in stalls of their own. Bosses (stall owners) usually provide a sale ground, merchandise as well as residences for dakocans. From table 1. it is known that most samples are 23-30 years old (64.06\%) with a

Nugraha, I. S. (2019). High-risk sexual behavior among dakocan (female coffee seller). 
larger proportion of dakocans coming from outside the Bali (62.5\%) compared to Bali. As large as (40.63\%) dakocans are subject to unmarried status research, the education levels of most subjects are junior high and high school (40.63\%), with long being 10-48 months (90.63\%) and the income of dakocans mostly above 3 million $(82.81 \%)$ of the proceeds of selling food and drinks in its stalls. Table 1. is presented below.

Table 1

Characteristics of Subjects

\begin{tabular}{|c|c|c|}
\hline Characteristics of Subjects & Frequency & $\%$ \\
\hline \multicolumn{3}{|l|}{ Age (year) } \\
\hline $23-30$ & 41 & 64.06 \\
\hline $31-37$ & 23 & 35.94 \\
\hline \multicolumn{3}{|c|}{ Ownership Status of Dakocan Wards } \\
\hline Own & 10 & 15.60 \\
\hline Boss's & 54 & 84.40 \\
\hline \multicolumn{3}{|l|}{ Origin Region } \\
\hline Bali & 24 & 37.50 \\
\hline Outside Bali & 40 & 62.50 \\
\hline \multicolumn{3}{|l|}{ Marriage Status } \\
\hline Not yet Mating & 26 & 40.63 \\
\hline Mating & 17 & 26.56 \\
\hline Widow & 21 & 32.81 \\
\hline \multicolumn{3}{|l|}{ Education } \\
\hline No School & 6 & 9.38 \\
\hline SD & 6 & 9.38 \\
\hline Junior High & 26 & 40.63 \\
\hline high school & 26 & 40.63 \\
\hline \multicolumn{3}{|l|}{ Long Being Dakocan (month) } \\
\hline$<10$ & 6 & 9.37 \\
\hline $10-48$ & 58 & 90.63 \\
\hline \multicolumn{3}{|l|}{ Sales Income } \\
\hline$<3$ millions & 11 & 17.19 \\
\hline$\geq 3$ millions & 53 & 82.81 \\
\hline Total & 64 & 100.00 \\
\hline
\end{tabular}

\subsection{An Overview of the Sexual Behavior of Risk in Dakocan}

An overview of risky sexual behavior in dakocan can be seen in table 2. It is known that knowledge regarding HIV/AIDS is lacking (59.38\%), perception of seriousness to the risk of STI and HIV/AIDS subjects is not serious (62.50\%), perception of vulnerability to the risk of STI and HIV/AIDS vulnerable subjects (67.19\%), perception of benefits to condom use in subscribers of subjects less (59.38\%), perception of obstacles in using condoms and accessing IMS/HIV-AIDS checks/HIV-AIDS checks subjects were hampered (51.56\%), Environmental support for using condoms and examining the health of good subjects (59.38\%), most subjects once had HIV/AIDS examination experience (71.88\%), subjects had the most non-risk sexual behavior (82.81\%) and subjects had the most never served sexual contact with customers (78.13\%). Of all subjects, only 14 people $(21.88 \%)$ claimed that in addition to selling food and drink, they also had sexual activity with customers in the form of fingering and holding, as well as performing various ways of sexual intercourse. Only 11 people (78.57\%) admitted that customers did not use condoms when sexually related. Table 2 . is presented below. 
Table 2

An overview of risk sexual behavior

\begin{tabular}{lll}
\hline Variable & Frequency & $\%$ \\
\hline Knowledge of HIV/AIDS & & \\
Good & 26 & 40.63 \\
Less & 38 & 59.38 \\
The Perception of Seriousness & 24 & 37.50 \\
Seriously & 40 & 62.50 \\
Not Seriously & & \\
Vulnerability Perception & 21 & 32.81 \\
No Vulnerability & 43 & 67.19 \\
Vulnerable & & \\
Benefits Perception & 26 & 40.63 \\
Good & 38 & 59.38 \\
Less & & \\
Obstacle Perception & 31 & 48.44 \\
Not Inhibited & 33 & 51.56 \\
Inhibited & & \\
Environmental Support & 38 & 59.38 \\
Good & 26 & 40.63 \\
Less & & \\
Experience of HIV/AIDS Examination & 46 & 71.88 \\
Ever & 18 & 28.13 \\
Never & & \\
Sexual Connection with Customer (n=64) & 14 & 21.88 \\
Ever Serve & 50 & 78.13 \\
Never Serves & & \\
Customers Not Use Condoms When Contacted Sexually & 11 & 78.57 \\
Risk & 3 & 21.43 \\
No-Risk & & \\
\hline
\end{tabular}

\subsection{Sexual Behavior of Risk}

Fisher Exact's test results on HIV transmission risk sexual behavior show that environmental support variables related to risky sexual behavior in good dakocan have a higher percentage $(28,95 \%)$ with a $p=0.002$ value means $\mathrm{p}<0.05$ thus statistically meaningful. Table 3 . is presented below.

Table 3

Sexual behavior at risk

\begin{tabular}{|c|c|c|c|}
\hline \multirow{2}{*}{ Variable } & \multicolumn{2}{|c|}{ Sexual Behavior of Risk } & \multirow{2}{*}{$\begin{array}{l}\text { 1-sided Fisher's } \\
\text { exact }\end{array}$} \\
\hline & $\begin{array}{l}\text { Risk } \\
\text { n (\%) }\end{array}$ & $\begin{array}{l}\text { No-Risk } \\
\mathrm{n}(\%)\end{array}$ & \\
\hline \multicolumn{4}{|l|}{ Age (year) } \\
\hline $23-30$ & $8(19.51 \%)$ & $\begin{array}{c}33 \\
(80.49 \%)\end{array}$ & 0.386 \\
\hline $31-37$ & $3(13.04 \%)$ & $\begin{array}{c}20 \\
(86.96 \%)\end{array}$ & \\
\hline $\begin{array}{l}\text { Origin Region } \\
\text { Bali }\end{array}$ & $3(12.50 \%)$ & 21 & 0.341 \\
\hline
\end{tabular}

Nugraha, I. S. (2019). High-risk sexual behavior among dakocan (female coffee seller). International Journal of Health Sciences, 3(3), 33-43. https://doi.org/10.29332/ijhs.v3n3.320 


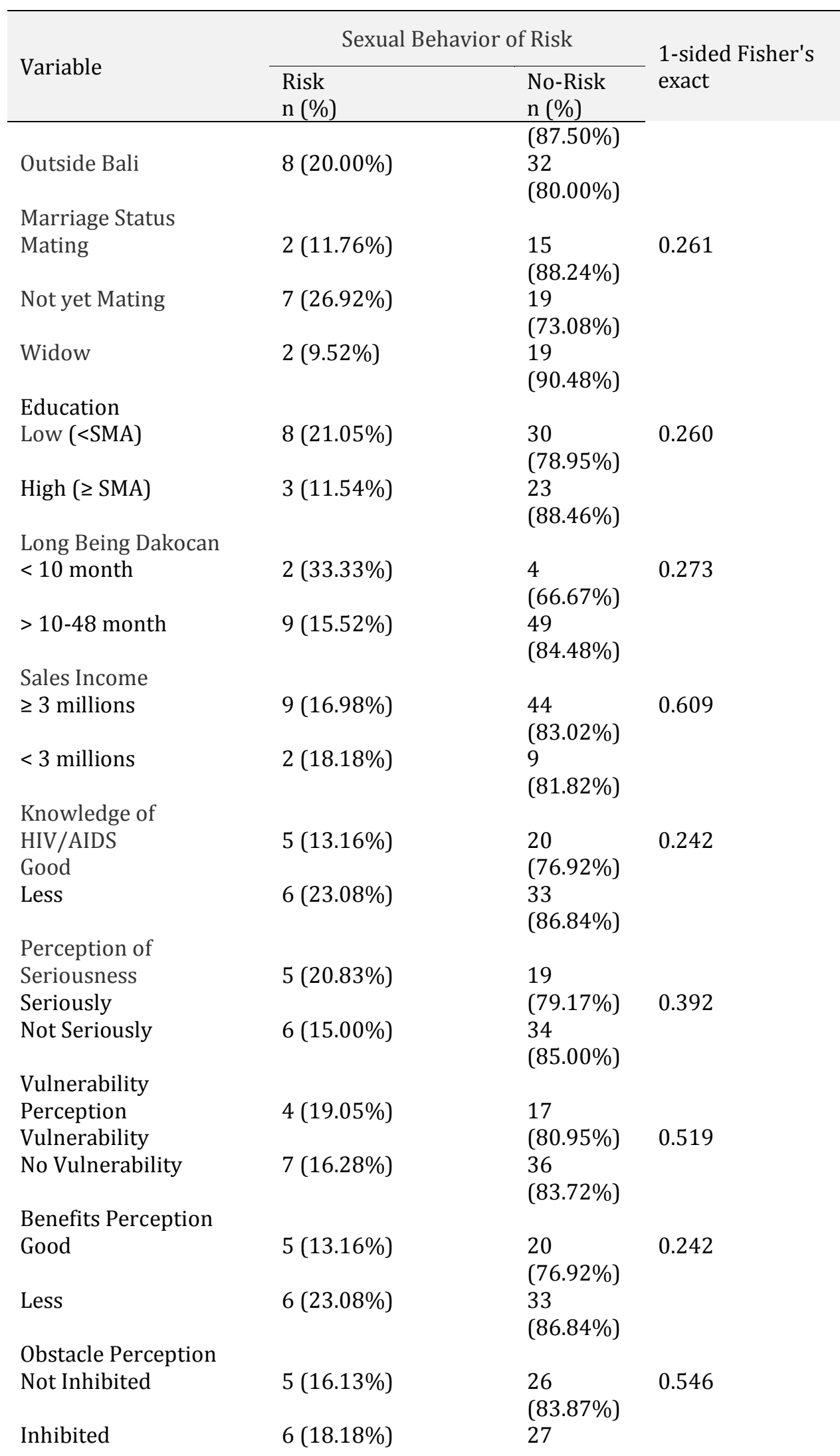




\begin{tabular}{|c|c|c|c|}
\hline \multirow{2}{*}{ Variable } & \multicolumn{2}{|c|}{ Sexual Behavior of Risk } & \multirow{2}{*}{$\begin{array}{l}\text { 1-sided Fisher's } \\
\text { exact }\end{array}$} \\
\hline & $\begin{array}{l}\text { Risk } \\
\mathrm{n}(\%)\end{array}$ & $\begin{array}{l}\text { No-Risk } \\
\mathrm{n}(\%)\end{array}$ & \\
\hline & & $(81.82 \%)$ & \\
\hline \multicolumn{4}{|c|}{ Environmental Support } \\
\hline Good & $11(28.95)$ & 27 (71.05) & 0.002 \\
\hline Less & $0(0.00)$ & $\begin{array}{l}26 \\
(100.00)\end{array}$ & \\
\hline \multicolumn{4}{|c|}{ Experience of HIV/AIDS } \\
\hline Ever & $8(17.39 \%)$ & $\begin{array}{l}38 \\
(82.61 \%)\end{array}$ & 0.630 \\
\hline Never & $3(16.67 \%)$ & $\begin{array}{l}15 \\
(83.33 \%)\end{array}$ & \\
\hline
\end{tabular}

\subsection{Influential Variables on the Sexual Behavior of HIV Transmission Risk}

The results of multivariate analysis showed that the most significant variables increase sexual behavior at risk of HIV transmission that is the variable perception of benefits to condom use in customers $(95 \% \mathrm{CI}=0.002$ 0.759; $\mathrm{p}<0.05)$ and HIV/AIDS examination $(95 \% \mathrm{CI}=1.039-182.903 ; \mathrm{p}<0.05)$. Table 4. is presented below.

Table 4

Adjusted OR Sexual Behavior of HIV Transmission Risk

\begin{tabular}{lllll}
\hline \multirow{2}{*}{ Variable } & \multirow{2}{*}{$\begin{array}{l}\text { Adjusted } \\
\text { OR }\end{array}$} & \multicolumn{2}{c}{ 95\%CI } & \\
\cline { 3 - 4 } & & $\begin{array}{l}\text { Lower } \\
\text { limit }\end{array}$ & $\begin{array}{l}\text { Upper } \\
\text { limit }\end{array}$ & P-value \\
\hline $\begin{array}{l}\text { Benefits Perception } \\
\text { Good }\end{array}$ & $1($ Ref $)$ & & & \\
$\begin{array}{l}\text { Less } \\
\text { Experience of }\end{array}$ & 0.44 & 0.002 & 0.759 & 0.032 \\
$\begin{array}{l}\text { HIV/AIDS Examination } \\
\text { Ever }\end{array}$ & & & & \\
Never & $1($ Ref $)$ & & & \\
& 13.7 & 1.039 & 182.903 & 0.047 \\
\hline
\end{tabular}

In-depth interviews were carried out on 14 dakocans in person and face-to-face explaining the problem of peer support for condom use, dakocan boss support, rewards for sexual intercourse services, experience of HIV / AIDS testing, perceptions of vulnerability to HIV transmission, perceived benefits in using condoms, perceived perceptions in using condoms, and sexual behavior risk of transmission of HIV / AIDS. The results of the environmental support show that the majority of the dakocans advise one another to use condoms during sexual relations with customers. Like the dakocan quote below.

"Once, once advised to be friends, once also in Surabaya was bidden with friends." (R.51)

The results of dakocan boss support showed that of 14 dakocan, four dakocans claimed to be advised using condoms on customers while serving sexual intercourse by bosses. Like the following phrase.

"My Boss is the same sort of officer who's here to use a condom.." (R.53)

The results of the interview on the reward of the service of sexual intercourse show that dakocans get minimal services of 100 thousand and a maximum of one million per one customer depending on service while sexually administered. As the phrase follows:

"Yes, the car can pay me 300 thousand, if it fits me a desert 100 thousand, it's okay."(R.38)

Nugraha, I. S. (2019). High-risk sexual behavior among dakocan (female coffee seller). 
The results of the interview on the experience of HIV/AIDS examination conducted by 14 dakocans, nine people admitted to having had HIV/AIDS-related health checkups although not routine on the grounds of no fee for conducting the examination unless there was a free check program. As the following phrase goes:

"If you check it out last year, free blood checks in the puskesmas have sent the officers here, mas.

There's a mas told to puskesmas to be loved by free condoms to." (R.53)

Most dakocans feel at risk of contracting HIV/AIDS disease and most dakocans perform the treatment by washing clean with betel soap and drinking antibiotics. Like the dakocan interview quote as follows.

"Well, if I take a bath, I'll clean up, keep ee..ee.. make miss v. I wash clean with betel soap, let's get a little germ." (R.38)

The interview results on perception of benefits to condom use in customers show that most dakocans admit to rarely offering condoms to customers for fear of customer loss and being unwilling to get less sexual services rewards so when sexually related to customers does not use condoms. Like the dakocan interview quote as follows.

"Emm... I've never been a condom, so I don't know, never offered. If you wear a condom I'll get paid

less. So don't wear a condom.." (R.28)

Perception of condom use barriers on dakocan suggests that of 14 dakocans, five dakocans claim to be afraid of losing customers if using condoms because customers are unwilling if related to using condoms and four dakocans claim to be in return for less acquired sex services if using condoms. Like the dakocan interview quote as follows.

"If you're wearing less paid condoms. So I don't use condoms because of the pay I can get more."

Customers who use condoms in the last month of 14 dakocans, namely five dakocans claim customers never use condoms and six dakocans admit customers rarely use condoms. Like the dakocan interview quote as follows.

"I rarely wear a condom if there's a free condom from the officers. Yeah, let alone a young customer, rarely want to use a condom." (R.53)

Serving customers of sexual intercourse that varies like oral sex and anal sex without using condoms on customers constitutes a service that a dakocan provides. Of the 14 dakocan, six dakocans admitted to having had oral sex. Like the dakocan interview quote as follows.

"Once, everything depends on customer demand. There are just a few people who ask for oral and anal sex. What matters is they pay more expensively." (R.38)

Within a month, the average dakocan serves nine customers. This number varies depending on proximity, dakocan interest with customers and the situation is held (for example during the fruit harvest season). Of the 14 dakocans admit to serving customers sexually related in a month that is as many as four customers at a minimum and as maximum as 30 customers. Like the dakocan interview quote as follows.

"Every month I can get customers 10-12, depending on the harvest season here. If you've harvested, customers are crowded and payable as much as extra tips." (R.38)

Research on HIV-sustaining risky sexual behavior on PSP-TL in Indonesia has been widely researched. However, mixed-method research on the determinant of sexual behavior risks HIV transmission in the trade of beautiful coffee (dakocan) in the Western Region of Buleleng Country has never been conducted. The results of this study showed that the most significant variables relate to sexual behaviors at risk of HIV transmission in dakocan namely perception of benefits to condom use in customers and the HIV/AIDS Experience Examination in dakocan.

Perception benefits against condom use in customers with a $\mathrm{p}=0.032(95 \% \mathrm{CI}=0.002-0.759 ; \mathrm{p}<0.05)$ value. It can be concluded that quantitative research results match qualitative research results suggesting that dakocans that have a perception of benefits to condom use in customers that lack the risk of HIV/AIDS transmission 0.44 times greater than dakocans that have a perception of benefits to condom use in good customers.

Some factors that cause dakocan do not utilize condoms when having sexual intercourse with customers namely less dakocan knowledge factors about condom benefits, low bargaining positions, the power to reject customers who are unwilling to use low condoms due to higher-acquired sexual services rewards if not using condoms, negative perceptions about the use of condoms that can prevent sexually transmitted diseases, and 
dakocan dissatisfaction in accessing condoms for free in pus or from accessing health care in pus. who came to the dakocan stall.

In line with research in Makasar showed that benefits to condom use in HIV/AIDS prevention were highly influential from the consistency of condom wear. Perceived perception of benefits is the perception of individual assessment subjects when using condoms as HIV/AIDS preventive efforts. The subject feels secure when using a condom (Rauf et al., 2018). Research results in the mounting port showed that the positive perception of the benefits to condom use is the most significant factor related to condom use behavior $(\mathrm{p}=0,000)$ (Sirait \& Sarumpaet, 2013).

The HIV/AIDS Experience Examination on dakocan in this study is most significant in relation to HIV transmission risk sexual behavior in dakocan obtained a $\mathrm{p}=0.047(95 \% \mathrm{CI}=1.039-182.903 ; \mathrm{p}<0.05)$. It can be concluded that quantitative analysis results are in accordance with qualitative research analysis suggesting that dakocans who never had HIV/AIDS examination experience had 13.7 times the risk of HIV/AIDS transmission is greater than dakocans who have HIV/AIDS examination experience. In line with the results of qualitative research in Buleleng showed that PSP's driving factors in accessing health services are related to early detection of STIs and HIV/AIDS in thrust based on awareness from the PSP itself, other PSP support, solicitation of friends or outsiders in accessing the service. As for the behavior of PSPs that can inhibit PSPs in accessing health services that are lack of information about health services, health facilities, check partners and medical expenses (Apriadi et al., 2016). Outreach by health care workers is essential in obtaining information so as to convert risky behaviors to non-risk. Regular visits from health workers on-site greatly provide benefits to female sex workers regarding the understanding of condom use in customers and PSP knowledge (Bugis \& Shaluhiyah, 2013).

The results of the study in Serdang Country stated that health care supports most deals with condom use measures $(p=0.005)$. Healthcare workers should provide continuous routine extensions on the benefits of condoms, the ways in which condoms use, and information regarding HIV/AIDS. In addition, Healthcare workers make a persuasive approach with coffee shop owners and dakocans (Sianturi, 2013).

Results in Batang Country research on factors affecting PSP-TL sexual behavior in HIV/AIDS prevention efforts in dim stalls suggest that pimp support, health service availability, HIV/AIDS vulnerability perception and perception of seriousness to HIV/AIDS disease are the most significant factors affecting sexual behavior in PSP-TL (Pratama, 2016).

\section{Conclusion}

Perception of benefits to the use of less condoms on dakocan because of the less dakocan knowledge factors about condom benefits, low bargaining positions, the power to reject customers who are unwilling to use low condoms because of the higher earned sexual services rewards if not using condoms, and the dakocan dissatisfaction in accessing condoms for free in Puskesmas (Community Health Center) or from health workers who come to dakocan stalls and most dakocans ever have had experience. STIs and HIV/AIDS though not routine once a month so vulnerable increases HIV transmission risk behavior.

\section{Acknowledgments}

We would like to thank YCUI, the enumerator, and the subjects participating in the study.

Nugraha, I. S. (2019). High-risk sexual behavior among dakocan (female coffee seller). 


\section{References}

Apriadi, I. P. Y., Kamayani, M. O. A., \& Damayanti, M. R. (2016). Perilaku pencarian pelayanan kesehatan terkait deteksi dini hiv/aids pada wanita penjaja seks di sawan buleleng. Coping (Community of Publishing in Nursing), 4(1).

Bugis, N., \& Shaluhiyah, Z. (2013). Peran Manager Karaoke Terhadap Praktik Penggunaan Kondom dalam Pencegahan IMS dan HIV/AIDS di Kota Ambon. Jurnal Promosi Kesehatan Indonesia, 8(2), 141-150. https://doi.org/10.14710/jpki.8.2.141-150

Dinas Kesehatan Kabupaten Buleleng. 2017. Profil Kesehatan Kabupaten Buleleng Tahun 2017. Singaraja: Dinas Kesehatan Kabupaten Buleleng

Ditjen P2P. (2017). Laporan Situasi Perkembangan HIV-AIDS \& PMS di Indonesia. Jakarta: Kementerian Kesehatan Republik Indonesia.

Ditjen P2P. (2018). Laporan Situasi Perkembangan HIV-AIDS \& PMS di Indonesia. Jakarta: Kementerian Kesehatan Republik Indonesia

Komisi Penanggulangan AIDS Daerah Kabupaten Buleleng. (2018). Estimasi Populasi Kunci dan Orang Dengan HIV/AIDS (ODHA) tahun 2018 di Kabupaten Buleleng. Buleleng: Komisi Penanggulangan AIDS Daerah Kabupaten Buleleng

Markolinda, Y., \& Sawirman, -. (2018). High risk of HIV towards sexual transaction, use of drugs, and lingual symbol of day-pay workers. International Journal of Health Sciences, 2(2), 68-77. https://doi.org/10.29332/ijhs.v2n2.161

Mulyani, S., Subiyanto, A., Anantanyu, S., Respati, S. H., \& Wiboworini, B. (2017). Path analysis: knowledge, motivation factor, and their relationship with readiness to provide exclusive breastfeeding among pregnant women. International Research Journal of Management, IT and Social Sciences, 4(1), 8-14.

Pratama, A. Y. (2016). Faktor-faktor yang mempengaruhi perilaku seksual wanita pekerja seksual tidak langsung (wpstl) dalam upaya pencegahan hiv/aids (Studi Kasus di Warung Remang-Remang Luwes Surodadi Gringsing Kabupaten Batang) (Doctoral dissertation, Universitas Negeri Semarang).

Rauf, D. A., Suryoputro, A., \& Shaluhiyah, Z. (2018). Analisis Hubungan Persepsi Manfaat Yang Dirasakan Terhadap Konsistensi Penggunaan Kondom Pada Waria Pekerja Seks Dalam Pencegahan HIV AIDS di Kota Makassar. Al-sihah: The Public Health Science Journal, 10(2). https://doi.org/10.24252/as.v10i2.6051

Ririanty, M., \& Nafikadini, I. (2015) 'Dakocan'dalam warung kopi sebagai penarik budaya 'ngopi” pada masyarakat kabupaten jember: Pandangan, Sikap dan Dampaknya terhadap Kesehatan Masyarakat di Kabupaten Jember Ketua Peneliti: Drs. Thohirun, MS, MA Anggota: Mury Ririanty, S. KM., M. Kes Iken Nafikadini, S. KM., M. Kes Universitas Jember November.

Sanjaya, D, B. (2013). Diseminasi HIV/AIDS Bagi Mahasiswa di Kabupaten Buleleng. Skripsi. Buleleng: Universitas Pendidikan Ganesha

Sianturi, S. A. (2013). Hubungan Faktor Predisposisi, Pendukung, Dan Penguat Dengan Tindakan Penggunaan Kondom Pada WPS Untuk Pencegahan HIV/AIDS Di Kabupaten Serdang Bedagai. Pre Cure, 1.

Sirait, L. M., \& Sarumpaet, S. (2012). Hubungan Komponen Health Belief Model (HBM) Dengan Peng-gunaan Kondom Pada Anak Buah Kapal (ABK) Di Pelabuhan Be-lawan. Pre Cure, 1.

UNAIDS. (2014). The Gap Report. Switzerland: Joint United Nations Programme on HIV/AIDS

UNAIDS. (2016). Prevention Gap Report. Switzerland: Joint United Nations Programme on HIV/AIDS

Yayasan Citra Usada Indonesia (YCUI). (2016). Laporan Pekerja Seks Perempuan Tidak Langsung (Dakocan) Di Buleleng Tahun 2016. Buleleng: YCUI 


\section{Biography of Author}

\begin{tabular}{||l|l||}
\hline \hline & $\begin{array}{l}\text { Iwan Saka Nugraha received his Bachelor of Pharmacy degree at the Faculty of } \\
\text { Mathematics and Natural Science (MIPA), Udayana University, Bali in 2014. In } \\
\text { 2015, he got a pharmacist degree at the Faculty of MIPA, Udayana University, Bali } \\
\text { and continued to master studies at Public Health Department, Medical Faculty, } \\
\text { Udayana University, Denpasar, Bali, Indonesia. He worked on a research on HIV } \\
\text { under the title Sexual Behavior of HIV Transmission Risk in Pretty Coffee Traders } \\
\text { (Dakocan) in the West of Buleleng Regency. } \\
\text { Email: saka.nugraha1@gmail.com }\end{array}$ \\
\hline
\end{tabular}

